\title{
Persepsi Siswa Tentang Faktor yang Mempengaruhi Minat Belajar
}

\begin{tabular}{|c|c|c|}
\hline \multicolumn{3}{|c|}{$\begin{array}{c}\text { Salim Korompot, Maryam Rahim, Rahmat Pakaya } \\
\text { Fakultas Ilmu Pendidikan, Universitas Negeri Gorontalo } \\
\underline{\text { salimkorompotung@gmail.com }}\end{array}$} \\
\hline Diterima: April 2020 & pril 2020 & Dipublikasi: Mei 2020 \\
\hline \multicolumn{3}{|c|}{$\begin{array}{l}\text { Abstrak } \\
\text { Belajar merupakan suatu aktivitas atau kegiatan yang berimplikasi pada suatu } \\
\text { perubahan ke arah maju menyangkut pengetahuan, sikap dan keterampilan. Untuk } \\
\text { mencapai kesuksesan belajar dibutuhkan faktor-faktor pendorong, dan salah satunya } \\
\text { adalah minat belajar. Penelitian ini menyangkut persespi siswa tentang faktor penyebab } \\
\text { rendahnya minat belajar. Penelitian ini menggunakan pendekatan deskripsi kuantitatif, } \\
\text { pengumpulan data menggunakan angket dan analisis data menggunakan analisis } \\
\text { persentase. Hasil penelitian menunujukkan bahwa dalam persepsi siswa penyebab } \\
\text { rendahnya minat belajar adalah aspek jasmani } 84 \% \text {, aspek psikologis } 78 \% \text {, aspek } \\
\text { keluarga } 72 \% \text {, aspek sekolah } 69 \% \text {, dan aspek masyarakat } 75 \% \text {. Berdasarkan kelima } \\
\text { indikator tersebut aspek jasmani yang memperoleh nilai rata-rata sebanyak }(84 \%) \text {. Hal } \\
\text { ini menunjukkan bahwa dalam persepsi siswa aspek jasmani merupakan faktor dominan } \\
\text { mempengaruhi minat belajar. } \\
\text { Kata kunci: Persepsi, Siswa, Minat Belajar }\end{array}$} \\
\hline \multicolumn{3}{|c|}{$\begin{array}{l}\text { Abstract } \\
\text { Learning is an activity which implies certain change into a better direction related to } \\
\text { knowledge, attitude, and skill. In achieving a learning success, it requires driving } \\
\text { factors, and one of them is interest to learn. This study was associated with students' } \\
\text { perception on the factor causing low interest in learning. The study used a quantitative } \\
\text { descriptive approach in which the data collection applied questionnaire, and the data } \\
\text { analysis used percentage analysis. The research finding showed that according to } \\
\text { students' perception, the causes of low interest in learning were physical aspect for } \\
84 \%, \text { psychological aspect for } 78 \% \text {, family aspect for } 72 \% \text {, school aspect for } 69 \% \text {, and } \\
\text { social aspect for } 75 \% \text {. Based on the previous five indicators, the psychological aspect } \\
\text { physical an average value of } 84 \% \text {, which indicates in students' perception, it was the } \\
\text { dominant factor which influencing to interest in learning. } \\
\text { Keywords: Perception, Student, Interest in Learning }\end{array}$} \\
\hline & $\begin{array}{l}\text { This is an op } \\
\text { Attribution } \\
\text { cited. C2020 } \\
\text { Pakaya }\end{array}$ & $\begin{array}{l}\text { ibuted under CC BY-SA } 4.0 \\
\text { ee original work is properly } \\
\text { t, Maryam Rahim, Rahmat }\end{array}$ \\
\hline
\end{tabular}

\section{PENDAHULUAN}

Belajar adalah istilah yang sering didengar, diamati, dan juga dianalisis proses dan hasilnya. Belajar merupakan serangkaian proses yang melibatkan berbagai hal yang dimiliki individu, terutama pelibatan panca indra yang berdampak pada keuntungan bagi individu yang melakukannya. Belajar dapat juga dimaknai dengan suatu aktivitas atau kegiatan yang berimplikasi pada suatu perubahan, menyangkut pengetahuan, sikap dan keterampilan. Belajar juga diyakini sebagai tindakan dan perilaku yang kompleks (Dimyati dan Mudjiono, 2010;7), dalam artian proses belajar seseorang akan melewati serangkaian tahapan yang kompleks sekaligus melibatkan berbagai upaya dan usaha, baik yang bersifat psikologis, sosial dan juga artikulasi keterampilan. Belajar meliputi tidak hanya mata 
pelajaran, tetapi juga penguasaan, kebiasaan, persepsi, kesenangan, minat, penyesuai sosial, bermacam-macam keterampilan, dan cita-cita (Hamalik, 2010;45).

Minat dalam belajar merupakan salah satu aspek dalam faktor psikologis mempengaruhi individu dalam belajar. Sebab dengan minat seseorang akan memiliki suatu rasa lebih suka dan rasa ketrikatan pada suatu hal atau aktivitas tanpa ada yang menyuruh (Djamarah, 2008;191). Minat belajar memiliki peran besar terhadap belajar, karena minat belajar menjadi salah satu kunci keaktifan seorang pebelajar. Demikian pula dengan siswa sebagai pebelajar, dengan adanya minat belajar akan berimplikasi pada proses dan hasil belajarnya.

Febriyanti dan Seruni $(2014 ; 253)$ dan juga Sirait (2016;41) memaparkan hasil penelitian meraka, bahwa seseorang yang memiliki minat belajar yang tinggi akan dapat mengikuti proses pembelajaran dengan baik sehingga akan mampu menghasilkan performa yang terbaik dalam belajarnya. Hal ini mengartikan bahwa minat belajar dapat diekspresikan oleh siswa dalam aktivitas sehari-hari sebagai seorang pebelajar, dimanifestasikan melalui partisipasi aktif dalam kegiatan belajar.

Siswa yang memiliki minat belajar akan menunjukkan kecenderungan perilaku perhatian dengan objek dan subjek yang dipelajarinya. Namun sebaliknya siswa yang bermasalah dengan minat belajarnya akan memperlihatkan perilaku yang tidak diharapkan, seperti kurang perhatian dengan mata pelajaran, siswa tidak mengerjakan pekerjaan rumah, tidak memiliki catatan pelajaran dengan baik. Dengan demikian perlu dilakukan pemahaman mendalam terkait dengan persepsi siswa tentang faktor-faktor penyebab minat belajar.

\section{Hakikat Minat Belajar dan Faktor yang Mempengaruhinya}

Minat dalam Kamus Besar Bahasa Indonesia (online), diartikan dengan kecenderungan hati yang tinggi terhadap sesuatu; gairah; keinginan. Serupa dengan Poerwanto (2010: 66) memaknai minat sebagai kecenderungan hati yang tinggi terhadap sesuatu. Djamarah (2008: 191) mengatakan minat adalah suatu rasa lebih suka dan rasa ketrikatan pada suatu hal atau aktivitas tanpa ada yang menyuruh. Rusmiati (2017;23) mengartikan minat sebagai karekteristik kemampuan untuk memusatkan perhatian dengan penuh kemauan pada suatu keadaan yang tergantung bakat dan lingkungan. Dalam kata lain bahwa minat merupakan karakteristik seseorang berupa kekuatan khusus yang terdapat didalam diri seseorang, yang kecenderungannya atau keinginannya sangat tinggi atau sangat suka terhadap sesuatu.

Terkait dengan belajar, maka tentu dapat dimaknai, bahwa minat belajar merupakan adanya karakteristik seseorang berupa kekuatan khusus yang terdapat didalam diri seseorang, yang kecenderungannya atau keinginannya sangat tinggi atau sangat suka terhadap belajar. Rusmiati $(2017 ; 23)$ mengatakan bahwa minat belajar diartikan sebagai karakteristik kemampuan dan pemusatan perhatian pada suatu masalah atau topik yang dibicarakan. Sedangkan menurut Fadilah $(2016 ; 116)$ minat belajar merupakan suatu kesukaan, kegiatan atau aktivitas akan mendukung kelancaran kegiatan belajar. Febriyanti dan Seruni (2014;249), menjelaskan bahwa minat belajar adalah keinginan siswa untuk belajar sehingga pada waktu siswa diberi pelajaran ia akan memperhatikan dan aktif 
berusaha untuk mengetahui dan mengerti pelajaran tersebut. Sementara Sirait $(2016 ; 38)$ menjelaskan bahwa minat belajar itu adalah perhatian, rasa suka, ketertarikan seseorang (siswa) terhadap belajar yang ditunjukkan melalui keantusiasan, partisipasi dan keaktifan dalam belajar. Dengan demikian dapat disimpulkan bahwa minat belajar, adalah karakteristik kemampuan seseorang, berupa kekuatan khusus yang terdapat didalam diri seseorang, yang kecenderungannya atau keinginannya sangat tinggi atau sangat suka terhadap belajar, yang termanifestasi dalam bentuk kesukaan, pemusatan perhatian, dan keaktifan pada kegiatan belajar.

Minat belajar yang ada pada diri seorang pebelajar, termasuk siswa terbentuk karena dipengaruhi oleh berbagai faktor. Minat itu tidak muncul dengan sendirinya akan tetapi banyak faktor yang dapat mempengaruhi munculnya minat belajar, ada beberapa faktor yang dapat mempengaruhi minat belajar siswa, yaitu: motif, perhatian, dan bahan pelajaran dan sikap guru (Rusmiati 2017;280). Sedangkan menurut Fadilah, 2016 ;116), bahwa aktor-faktor yang mempengaruhi minat belajar yaitu, motivasi, sikap terhadap guru dan pelajaran, keluarga, fasilitas sekolah, dan teman pergaulan, minat belajar dipengaruhi oleh faktor-faktor yang saling berhubungan erat dan tidak dapat berdiri sendiri.

Dalam artian secara umum faktor yang mempengaruhi minat belajar dikategorikan dalam dalam dua faktor, yakni faktor dari dalam diri dan faktor dari luar indidvidu. Faktor intern merupakan faktor yang mampu menumbuhkan minat seseorang karena adanya kesadaran dari diri sendiri tanpa ada paksaan dari orang lain seperti faktor emosional, persepsi, motivasi, bakat dan penguasaan ilmu pengetahuan. Sedangkan faktor ekstern yaitu faktor yang mampu menumbuhkan minat seseorang akibat adanya peran orang lain dan lingkungan yang ada di sekitar seperti faktor lingkungan keluarga dan lingkungan sosial (Ardyani dan Latifah, 2014;233).

Al Fuad dan Zuraini (2016:4-5) menjelaskan faktor-faktor yang mempengaruhi minat belajar yaitu: Pertama, faktor dari dalam/internal, yang terdiri dari: (a) aspek jasmaniah, mencakup kondisi fisik atau kesehatan jasmani dari individu siswa, kondisi fisik yang prima sangat mendukung keberhasilan belajar dan dapat mempengaruhi minat belajar, (b) aspek psikologis/ kejiwaan, meliputi perhatian, pengamatan, tanggapan, fantasi, ingatan, berfikir, bakat,dan motif. Kedua, faktor dari luar siswa/eksternal, yang meliputi (a) keluarga, merupakan lembaga pendidikan pertama bagi anak, orang tua harus selalu siap sedia saat anak membutuhkan bantuan, menyediakan peralatan belajar yang dibutuhkan anak, menciptakan suasana yang nyaman mendukung anak dalam belaja, (b) sekolah, meliputi metode mengajar, kurikulum, sarana dan prasarana belajar, sumber-sumber belajar, media pembelajaran, hubungan siswa dengan teman, guru dan staf sekolah serta berbagai kegiatan kokurikuler, (c) lingkungan masyarakat, meliputi hubungan dengan teman bergaul, kegiatan dalam masyarakat, dan lingkungan tempat tinggal, kegiatan akademik, akan lebih baik apabila diimbangi dengan kegiatan di luar sekolah.

\section{METODE}

Penelitian ini menggunakan metode deskriptif kuantitatif. Penelitian ini dilaksanakan di SMA Negeri 1 Telaga, Kabupaten Gorontalo, dengan indikator: aspek 
jasmaniah, aspek psikologis, aspek keluarga, aspek sekolah, dan aspek lingkungan masyarakat.

Populasi 256 siswa dan sampel 38 orang, dengan teknik pengumpulan data menggunakan angket yang telah dilakukan uji validitas dan reliabilitas angket, dengan menggunakan pengukuran skala likert. Uji validitas menggunakan rumus Product Moment berikut ini:

$r_{x y}=\frac{n\left(\Sigma_{x y}\right)-\left(\Sigma_{N}\right)\left(\Sigma_{y}\right)}{\left.\sqrt{\left[n \cdot \sum x^{2}\right.}-\left(\sum x\right)^{2}\right]\left[n \sum Y^{2}-(\Sigma Y)^{2}\right]}$

Uji Realibilitas instrumen ini menggunakan metode Alpha, dengan rumus:

$$
r=\left[\frac{k}{(k-1 S)}\right]\left[1-\frac{\sum S_{i}}{\sum S_{t}}\right]
$$

Berdasarkan hasil perhitungan reliabilitas instrument, dengan nilai $r$ tabel $n=0,325$ dan taraf signifikannya adalah 1,031 maka di dapat nilai reliabilitas instrument $(r)=1,031>r$ tabel $=0,325$ perbandingan ini menunjukan hasil yang signifikan dengan kata lain instrument ini baik atau dapat di percaya. Analisis data menggunakan teknik analisa persentase: $p=f / n \times 100 \%$.

\section{HASIL TEMUAN}

Data hasil penelitian ini diperoleh dari sebaran angket yang mengacu pada indikator: aspek jasmaniah, aspek psikologis, aspek keluarga, aspek sekolah, dan aspek lingkungan masyarakat;

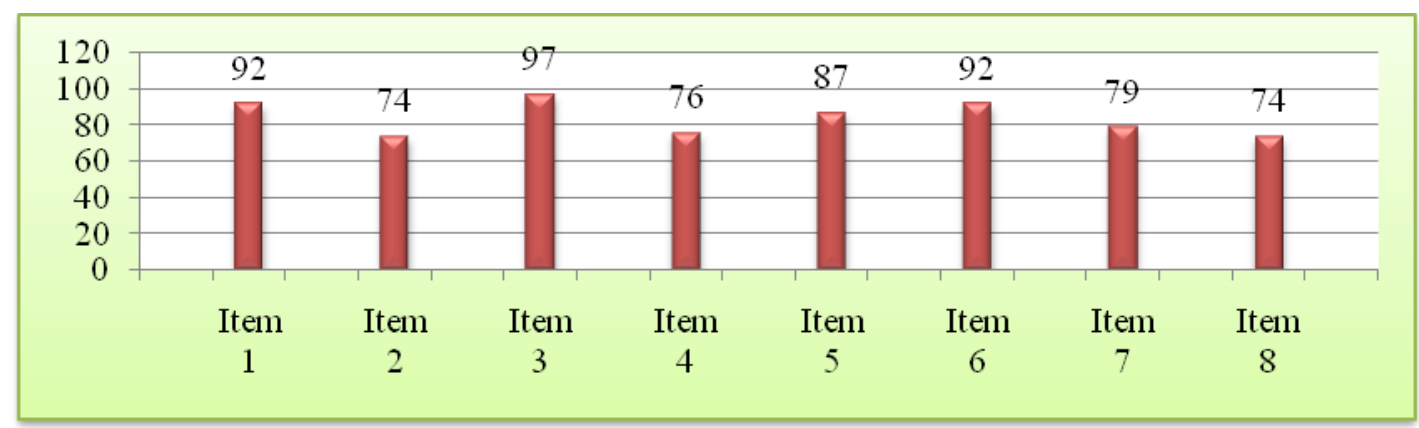

Grafik 1. Aspek jasmaniah

Berdasarkan Grafik 1. dapat dilihat bahwa persentase rata-rata siswa adalah $84 \%$, hal ini mengartikan bahwa sebagian besar siswa memandang aspek jasmaniah menjadi faktor yang mempengaruhi minat belajar. Aspek jasmaniah berkaitan dengan pandangan siswa tentang, 92\% siswa belajar dengan baik dan fokus karena sebelumnya sudah sarapan (item 1), 74\% siswa mudah mengantuk pada saat menerima mata pelajaran karena setiap malam sering tidur pukul 00:00 malam (item 2), 97\% siswa membiasakan mandi lebih pagi sebab ingin menerima proses pembelajaran dengan baik (item 3), 76\%\% siswa tidak sulit mambaca dengan jarak yang terlalu jauh (item4), 87\% pikiran siswa menjadi rileks dan dapat menerima pembelajaran dengan baik karena sering berolahraga (item 5), 92\% siswa dapat mendengarkan dengan jelas yang di sampaikan guru (item 6), 79\% siswa merasa 
nyaman belajar tiap pagi karena membiasakan tidur lebih awal (item 7), dan 74\% siswa sulit konsentrasi dalam belajar jika dalam keadaan lapar (item 8).

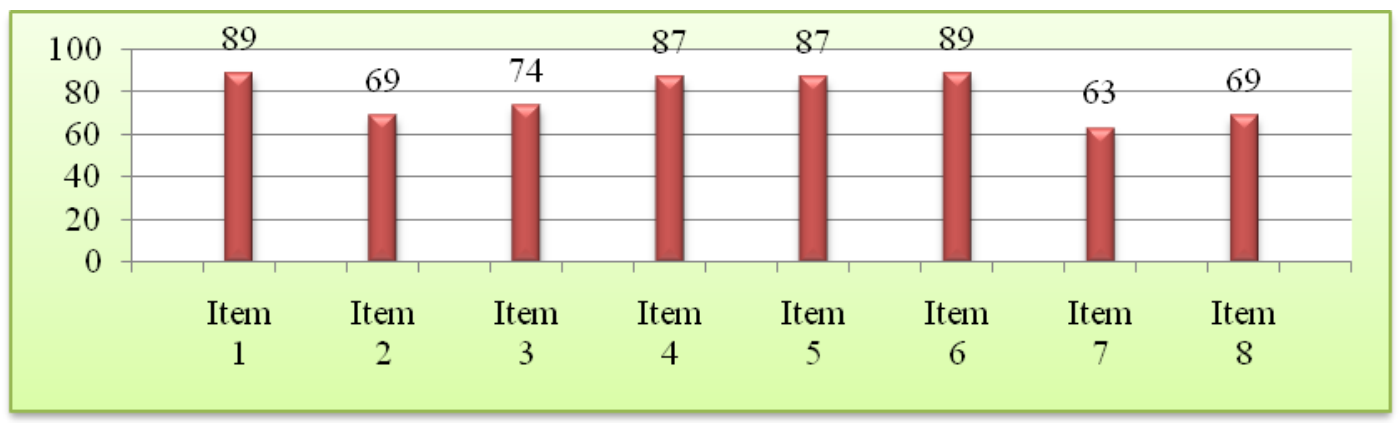

Grafik 2. Aspek psikologis

Berdasarkan Grafik 2. dapat dilihat bahwa persentase rata-rata siswa adalah 78\%, hal ini mengartikan bahwa siswa memandang aspek psikologis dapat mempengaruhi minat belajar. Aspek psikologis berkaitan dengan pandangan siswa tentang 89\% siswa cepat memahami apa yang di jelaskan guru karena sering memperhatikan apa yang di sampaikannya (item 1), 69\% siswa merasa puas belajar karena dapat mengerjakan soal dan memperoleh nilai yang baik (item 2), 74\% tidak lupa materi yang di sampaikan guru, karena mencatat apa yang di sampaikan (item 3), 87\% tidak mengalami kesulitan belajar karena selalu berusaha lebih baik (item 4), 87\% siswa tidak merasa kecewa dan tetap belajar lagi karena mendapat nilai yang jelek (item 5), 89\% siswa tidak merasa kesulitan pada saat ujian karena memiliki semangat untuk menemukan jawabanya (item 6), 63\% siswa bertanya kepada guru apabila ada materi yang kurang dipahami (item 7), dan 69\% siswa dapat mengerjakan pekerjaan rumah (PR) karena merasa senang mendapat tugas dari guru (item 8).

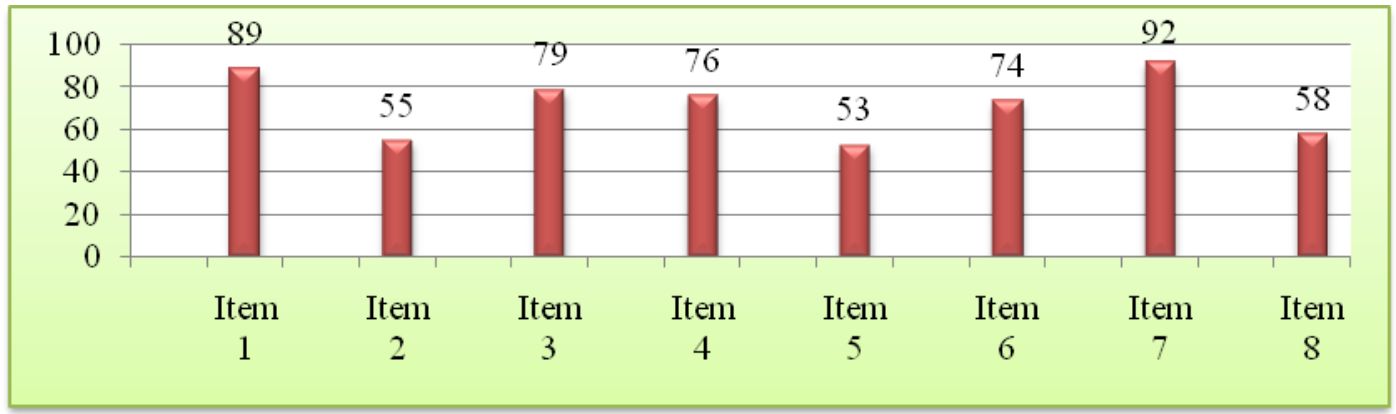

Grafik 3. Aspek keluarga

Berdasarkan Grafik 3. dapat dilihat bahwa persentase rata-rata siswa adalah $72 \%$, hal ini mengartikan bahwa siswa memandang aspek keluarga dapat mempengaruhi minat belajar. Aspek psikologis/kejiwaan berkaitan dengan pandangan siswa tentang, 89\% siswa merasa semangat karena orang tua selalu memotivasi untuk rajin belajar (item 1), 55\% siswa tetap merasa nyaman belajar di rumah meskipun harus membantu pekerjaan orang tua (item 2), 79\% siswa merasa orang tua selalu menggingatkan saya agar tidak bermain 
hp pada saat belajar karena itu dapat mengganggu konsentrasi belajar (item 3), 76\% siswa merasa mendapat perhatian dari orangtua meskipun mereka sibuk dengan pekerjaan mereka (item 4), 53\% orang tua tidak memberikan hukuman meskipun siswa gagal mencapai prestasi dalam belajar (item 5), 74\% siswa merasa lebih giat dalam belajar karena apabila mendapat juara kelas orang tua menjanjikan hadiah (item 6), 92\% siswa merasa senang karena orang tua selalu menasehati agar supaya mengulang mata pelajaran yang saya dapatkan di sekolah (item 7), dan 58\% siswa merasa tidak semangat belajar apabila tidak ada motivasi dari orang tua (item 8).

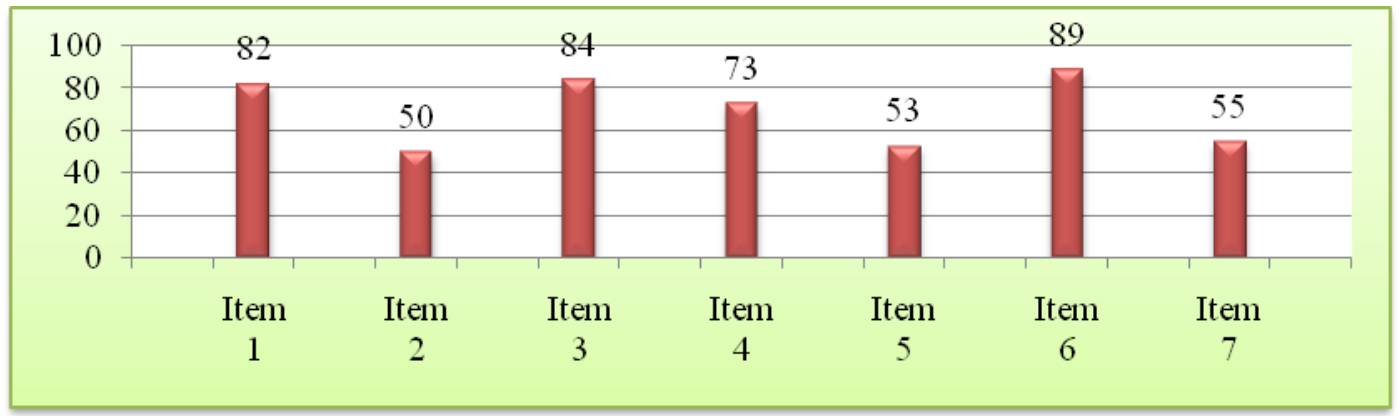

Grafik 4. Aspek sekolah

Berdasarkan Grafik 4. dapat dilihat bahwa persentase rata-rata siswa adalah 69\%, hal ini mengartikan bahwa siswa memandang aspek sekolah dapat mempengaruhi minat belajar. Aspek sekolah berkaitan dengan pandangan siswa tentang, 82\% siswa memperhatikan guru pada saat menjelaskan karena ingin memahami apa yang di sampaikan oleh guru (item 1), 50\% siswa tidak fokus menerima pelajaran diwaktu siang karena keadaan ruang kelas mulai panas (item 2), 84\% merasa senang apabila belajar di perpustakaan karena ruangannya sejuk (item 3), 73\% siswa mengikuti proses pembelajaran di kelas meskipun asik bermain dengan teman-teman (item 4), 53\% siswa fokus belajar meskipun ruangan kelas sangat kotor (item 5), 89\% merasa nyaman karena guru saya dapat mencairkan suasana dan mudah di pahami (item 6), dan 55\% siswa merasa yaman belajar meskipun penerangan pada ruangan kelas kurang memadai untuk belajar (item 7).

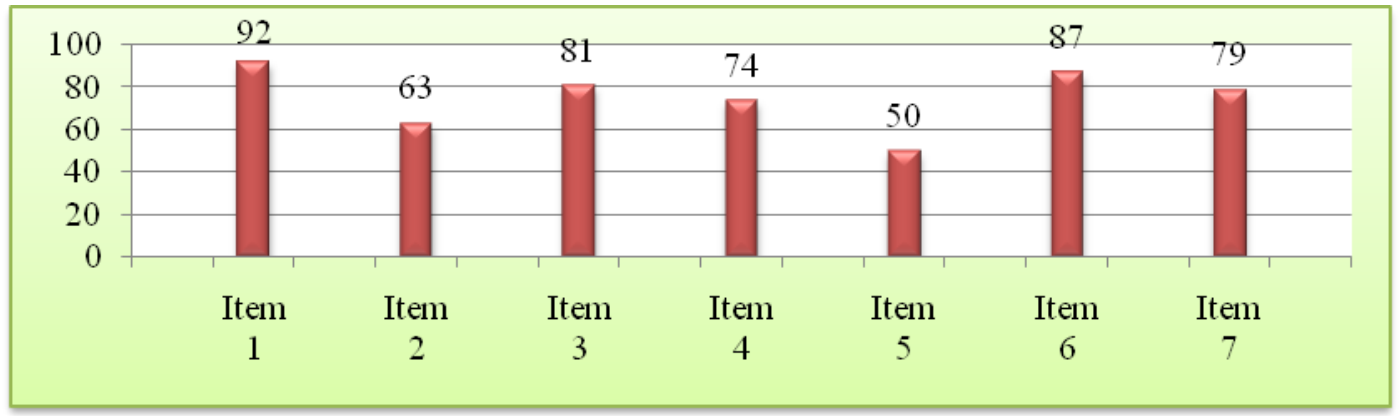

Grafik 5. Aspek lingkungan masyarakat

Berdasarkan Grafik 5. dapat dilihat bahwa persentase rata-rata siswa adalah $75 \%$, hal ini mengartikan bahwa siswa memandang aspek lingkungan masyarakat mempengaruhi minat belajar. Aspek lingkungan masyarakat berkaitan dengan pandangan siswa tentang, 92\% siswa merasa termotifasi belajar karena melihat orang-orang sukses di masyarakat 
(item 1), 63\% siswa tidak merasa terganggu pada saat belajar karena tetangga kami sering bertengkar (item 2), 82\% siswa sering mengikuti kegiatan yang di laksanakan dilingkungan kami karena itu dapat menambah pengalaman (item 3), 74\% siswa membantu orang tua meskipun asik bermain dengan teman kompleks (item 4), 50\% sering mendapatkan informasi belajar karena banyak membaca koran (item 5), 87\% siswa senang membuka internet di hp karena banyak informasi belajar (item 6), dan 79\% siswa tidak lupa mengerjakan pekerjaan rumah (PR), meskipun sedang bermain playstation dengan temanteman kompleks.

\section{PEMBAHASAN}

Berdasarkan data hasil penelitian menunjukkan bahwa siswa memandang aspek jasmani (84\%) dan aspek psikologis (78\%) merupakan aspek yang paling mempengaruhi minat belajar. Hal ini megartian bahwa faktor internal siswa merupakan faktor yang paling utama diperhatikan dalam meningkatkan minat belajarnya. Dengan demikian dapat dikatakan guna meningkatkan minat belajar siswa, maka perlu mengasah aspek jasmani dan aspek psikologis siswa, agar siswa tetap prima dalam menjalani aktivitas belajarnya, sekaligus memiliki mental yang bersemangat dan senang dalam belajar. Untuk mengoptimalkan aspek jasmani dan aspek psikologis, perlu pembiasaan hidup sehat dan bersemangat. Agar menjadikan kondisi jasmani dan psikologis siswa senantiasa selalu terjaga dengan baik dan baik, perlu dilakukan upaya penciptaan kondisi jasmani yang bugar. Beberapa komponen kebugaran jasmani, yakni: kekuatan (strenght), daya (power), kecepatan (speed), kelentukan (flexibility), daya tahan otot (muscular endurance), dan daya tahan umum (circulorespiration endurance)(Nurhasan, dalam Saputra, 2017), sekaligus menginternalisasikan pendekatan psikologis melalui melalui pendekatanpendekatan yang lebih berpusat pada siswa dan penciptaan suasana psikologis yang menyenangkan dan membahagiakan.

Sedangkan hasil penelitian terkait aspek keluarga, aspek sekolah, dan aspek lingkungan masyarakat, menunjukkan bahwa siswa memandang aspek lingkungan masyarakat (75\%), lebih mempengaruhi minat belajar, dibandingkan aspek keluarga (72\%), dan aspek sekolah (69\%). Hal ini memberikan makna bahwa penciptaan lingkungan yang akrab dan bersahabat dengan suasana belajar siswa, akan mempengaruhi minat belajar siswa. Dengan kata lain bahwa, apapun bentuk lingkungan tersebut dan memiliki kedekatan dan keakraban dengan siswa, maka akan tercipta minat belajar anak terkait lingkungan tersebut. Guna memaksimalkan aspek lingkungan masyarakat dalam upaya peningkatan minat belajar siswa, maka diperluka berbagai kegiatan sesuai dengan kondisi siswa. Nisa dan Setiyani $(2016 ; 658)$, mengatakan jika orang tua memperhatikan pendidikan anaknya tentunya timbul rasa semangat dan minat yang tinggi untuk belajar, dengan adanya minat dan perhatian siswa dalam belajar maka kondisi belajar akan berjalan secara efektif, sebab eluarga merupakan lembaga pertama yang mengajar dan mendidik sisswa dalam konteks belajar dan bersosial. Demikian pula dengan aspek sekolah sebagai lembaga pendidikan formal, perlu melakukan berbagai pendekatan dan kegiatan untuk menggali dan meningkatkan minat belajar siswa, seperti memperhatikan kompetensi guru (Nisa dan Setiyani, 2016), gaya mengajar guru (Mahyudi, 
2012), dan penggunaan media pembelajaran yang sesuai dengan kondisi dan kebutuhan siswa (Tafonao, 2018).

\section{SIMPULAN}

Penelitian menunjukan bahwa siswa mempersepsikan aspek jasmani (84\%) dan aspek psikologis (78\%) merupakan aspek yang paling mempengaruhi minat belajar, selanjutnya aspek lingkungan masyarakat (75\%), aspek keluarga (72\%), dan aspek sekolah (69\%). Hal ini megartian bahwa aspek jasmani dan aspek psikologis (factor

internal) siswa merupakan faktor yang paling utama diperhatikan dalam meningkatkan minat belajarnya. Dengan demikian dalam rangka menggali dan mengembangkan minat belajar siswa perlu dilakukan pendekatan dan pengembangan kegiatan yang sesui dengan kebutuhan siswa dan kondisi lingkungan siswa.

\section{DAFTAR PUSTAKA}

Al Fuad, Zaki dan Zuraini. 2016. Faktor-Faktor yang Mempengaruhi Minat Belajar Siswa Kelas I SDN 7 Kute Panang. Jurnal Tunas Bangsa 3 (2).

Ardyani, Anis dan Latifah, Lyna .2014. Analisis Faktor-Faktor yang Mempengaruhi Minat Mahasiswa Menjadi Guru Akuntansi Pada Mahasiswa Prodi Pendidikan Akuntansi Angkatan 2010 Universitas Negeri Semarang. Economic Education Analysis Journal. 3 (2) (2014).

Daniyati, Nadzifah Ajeng dan Sugiman. 2015. Hubungan Antara Kemampuan Verbal, Kemampuan Interpersonal, dan Minat Belajar dengan Prestasi Belajar Matematika. PYTHAGORAS: Jurnal Pendidikan Matematika Volume 10 - Nomor 1, Juni 2015, (50-60).

Dimyati, Dr dan Mudjiono, Drs. 2010. Belajar dan Pembelajaran. Cetakan keempat. Rineka Cipta. Jakarta.

Djamarah, B. Syaiful (2008). Psikologi Belajar. Jakarta: Rineka Cipta.

Fadillah, Ahmad. (2016). Analisis Minat Belajar dan Bakat Terhadap Hasil Belajar Matematika Siswa. M a t h 1 i n e: Jurnal Matematika dan Pendidikan Matematika. Volume 1 Nomor 2. Augustus 2016.

Febriyanti, Chatarina dan Seruni. 2014. Peran Minat dan Interaksi Siswa dengan Guru dalam Meningkatkan Hasil Belajar Matematika. Jurnal Formatif 4(3): 245-254. 2014.

Hamalik, Oemar, Dr. 2010. Psikologi Belajar dan Mengajar. Cetakan ketujuh. Sinar Baru Algensindo. Bandung.

Kamus Besar Bahasa Indonesia (online). https://kbbi.web.id/minat 
Mahyudi, Surya. 2012. Peranan Gaya Mengajar Guru Fisika Terhadap Minat Belajar Fisika Siswa Kelas IX MTs Istiqlal Delitua. Jurnal Pendidikan Fisika. Vol. 1 No. 1 Juni 2012.

Nisa, Indah Khoirul dan Setiyani, Rediana. 2016. Pengaruh Kompetensi Pedagogik, Lingkungan Keluarga dan Minat Belajar Terhadap Prestasi Belajar Mata Pelajaran Ekonomi. Economic Education Analysis Journal 5(2) (2016).

Poerwanto, Ngalim. (2010). Psikologi Pendidikan. Bandung: Remaja Rosdakarya.

Rusmiati. 2017. Pengaruh Minat Belajar Terhadap Prestasi Belajar Bidang Studi Ekonomi Siswa MA Al Fattah Sumbermulyo. Utility: Jurnal Ilmiah Pendidikan dan Ekonomi Volume 1, No. 1, Februari 2017: Page 21-36.

Saputra, Wahyu, M.Pd. 2017. Efek Mengikuti Ektra Kurikuler Olah Raga dan Tingkat Kebugaran Jasmani Terhadap Pembentukan Self-Esteem Siswa di Sekolah Menengah Kejuruan (SMK). Didaktik: Jurnal Pendidikan Guru Sekolah Dasar, ISSN : 24775673. Sekolah Tinggi Keguruan dan Ilmu Pendidikan Subang. Volume III Nomor 1, Desember2017.

Sirait, Erlando Doni. 2016. Pengaruh Minat Belajar Terhadap Prestasi Belajar Matematika. Jurnal Formatif 6(1): 35-43, 2016.

Tafonao, Talizaro. 2018. Peranan Media Pembelajaran dalam Meningkatkan Minat Belajar Mahasiswa. Jurnal Komunikasi Pendidikan, Vol.2 No.2, Juli 2018. 